\title{
Induction of Apoptosis by Ethanol Extract of Scutellaria baicalensis in Renal ell Carcinoma Caki-1 Cells
}

\author{
Won Deok Hwang', Yong-Gyun Im', Byoung Yil Son ${ }^{3}$, Cheol Park', Dong II Park ${ }^{1}$ and Yung Hyun Choi ${ }^{2,3,5}{ }_{\star}$ \\ Departments of ${ }^{1}$ Internal Medicine and ${ }^{2}$ Biochemistry, Dongeui University College of Oriental Medicine, Busan $614-052$ \\ ${ }^{3}$ Blue-Bio Industry Regional Innovation Center \& ${ }^{5}$ Anti-Aging Research Center, ${ }^{4}$ Department of Molecular Biology, College of Natural Sciences, \\ Dongeui University, Busan 614-714; Dongeui University, Busan 614-714, Korea
}

Received January 26, 2013 /Revised April 11, 2013 /Accepted April 18, 2013

\begin{abstract}
Scutellaria baicalensis, belonging to the family Labiatae, is widely distributed in Korea, China, Mongolia, and eastern Siberia. It has been used in traditional medicine for various diseases, such as dysentery, pyrexia, jaundice, and carbuncles. In addition, $S$. baicalensis is reported to possess various beneficial pharmacological activities, including anti-inflammatory, antidiabetic, antiviral, antihypertension, antioxidant, and anticancer effects. However, the molecular mechanisms of its anticancer activity have not been clearly elucidated. In the present study, we investigated the proapoptotic effects of ethanol extract of $S$. baicalensis (EESB) on human renal cell carcinoma Caki-1 cells. The anti-proliferative activity of EESB was associated with apoptosis induction, which was associated with the up-regulation of death receptor 4, the Fas ligand, and Bax and the down-regulation of Bid, XIAP, and cIAP-1 proteins. EESB treatment also induced mitochondrial dysfunction, proteolytic activation of caspase-3, -8 , and -9 and degradation of caspase- 3 substrate proteins, such as poly (ADP-ribose) polymerase, $\beta$-catenin, and phospholipase C- $\gamma 1$. However, pretreatment of a pan-caspase inhibitor, z-VAD-fmk, significantly attenuated the EESB-induced apoptosis. Taken together, these findings suggest that EESB may be a potential chemotherapeutic agent. Further studies will be needed to identify the active compounds that confer the anticancer activity of $S$. baicalensis.
\end{abstract}

Key words : Scutellaria baicalensis, renal cell carcinoma, apoptosis, caspase

\section{서 론}

최근 식생활의 서구화 및 생활수준의 지속적인 향상에 따라 암의 발생이 급격하게 증가되고 있는 추세이며, 여전히 암 발 생기전 해석 및 치유에 대한 명확한 방법이 정립되지 못해 난치성 질병으로 분류되고 있다[31]. 신세포암(renal cell carcinoma)은 원발성 신종양의 약 $85 \%$ 를 차지하는 악성종양으로 서, 신장실질(renal parenchyma)에서 주로 발생하며, 최초 진 단 시 약 25 30\%에서 이미 전이가 진행되어 있는 것으로 알 려져 있다[3, 7]. 노년층에서 주로 발생하고 있는 신세포암은 우리나라의 경우에도 남성에서 발생하는 암 중 $2.0 \%$ 로 10 위, 여성에서는 $1.2 \%$ 로 15 위를 차지하고 있으며, 최근 지속적인 증가 추세를 보이고 있다. 일반적으로 신세포암이 다른 기관 으로 전이되지 않은 경우에는 신장과 그 주위 정상 조직을

\section{*Corresponding author}

Tel : +82-51-850-7413, Fax : +82-51-853-4036

E-mail : choiyh@deu.ac.kr

This is an Open-Access article distributed under the terms of the Creative Commons Attribution Non-Commercial License (http://creativecommons.org/licenses/by-nc/3.0) which permits unrestricted non-commercial use, distribution, and reproduction in any medium, provided the original work is properly cited.
광범위하게 절제하는 근치적 신적출술(radical nephrectomy) 로 약 $60 \sim 70 \%$ 의 환자에서 5년 생존율을 기대할 수 있으나 전이가 진행된 신세포암의 경우는 현재까지 뚜렷한 치료법이 없는 실정이다[34]. 현재까지 vinblastine이 유용한 임상적 화 학요법제로 알려져 있으나 반응율은 $10 \%$ 내외로서 매우 낮은 수준이며, 전이가 유발된 신세포암의 경우에는 대개 급속히 진행되어 대부분이 2년 이내에 사망하는 것으로 알려져 있다 $[13,42]$. 따라서 신세포암을 치료하는데 있어서 보다 더 효과 적인 후보물질을 발굴하고 분자 및 세포 수준에서의 기전을 밝히는 것이 중요할 것이다.

암을 치료하기 위하여 사용되어지는 여러 가지 방법 중에서 암세포의 죽음을 유발시키는 것이 효율적인 치료방법으로 대 두되고 있다. 이러한 암세포의 죽음은 크게 세포괴사 (necrosis)와 자가세포사멸(apoptosis)의 과정으로 구별될 수 있으며, 이는 세포의 형태적 및 생화학적 특성에 의하여 구분 된다 $[17,39,50]$. 먼저 감염이나 조직손상에 의하여 발생하는 비정상적인 과정인 necrosis는 세포를 둘러싼 환경이 급격하 게 변하여 세포가 더 이상 적응할 수 없으면 세포의 팽창, 이온 농도의 변화 및 물의 유입등과 같은 조절되지 않는 상태로 유발되는 세포의 죽음으로서 에너지 비의존적이며 necrosis가 
유발된 세포의 내용물이 유출 또는 방출되어 근처에 위치한 세포에 영향을 미치게 되며 면역 반응의 손상을 유발하기도 한다 [8, 21, 38]. 그러나 programmed cell death라고도 불리는 apoptosis는 생리학적 과정으로서 태아의 형태형성, 난자의 배란, 신경세포의 시냅스 형성 등과 같은 개체의 발생단계에 서 정상적인 발달과 분화에 관여할 뿐 만 아니라 DNA 손상, 바이러스 감염 등에 의한 체내 비정상적인 세포들을 제거하는 기전으로서 유전적 조절 하에서 일어나는 정교한 개체의 생존 을 위한 방어기전이다[30, 54]. 따라서 apoptosis의 균형은 개 체 유지에 중요한 역할을 하지만 apoptosis 과정이 실패하게 되면 암과 같은 여러 가지 질병의 원인이 되는 것으로 알려져, apoptosis는 암화 과정의 여러 단계에서 암을 치료하는 중요 한 표적이 되고 있다[20].

꿀풀과(Labiatae)에 속하는 여러해살이 초본식물인 황금(黃 芩, Scutellaria baicalensis)은 중국이 원산지이며 약용식물로 도 입되어 전국에서 재배되고 있는 다년생 초본으로서 한국, 중 국, 몽골 및 시베리아 동부 등지에 분포한다. 황금은 해열, 이 뇨, 지사, 이담 및 소염제로서의 효능을 가지고 있으므로 예로 부터 민간처방 약재로 사용되었을 뿐만 아니라 한방에서는 뿌리를 말린 것을 이질(dysentery), 발열(pyrexia), 황달 (jaundice) 및 옹(carbuncle)의 치료제로 사용되고 있다[19, 27]. 최근 연구에 따르면 황금에는 활성성분으로 baicalein, biacalin, chrysin, oroxylin-A, wogonin 및 wogonoside 등과 같은 30 여종 이상의 flavonoid가 함유되어 있으며, 항염증, 항당뇨, 항균, 항알레르기, 항바이러스, 항고혈압 및 항산화 등과 같은 많은 약리학 및 생물학적 활성을 가지는 것으로 알려져 있다 $[4,7,16,19,23,32,37,51]$. 또한 황금은 많은 인체 암세포에 있어서 세포주기 억제 및 apoptosis 유발을 통한 항암활성을 가지는 것으로 보고되어지고 있으나, 신세포암에서의 항암효 능 및 분자생물학적 기전에 대해서는 명확히 밝혀져 있지 않 다[15, 40, 52].

본 연구에서는 황금의 에탄올 추출물(ethanol extract of $S$. baicalensis, EESB)이 인체 신세포암인 Caki-1 세포에 미치는 항암 효과의 생화학적 기전의 해석을 위하여 암세포의 증식에 미치는 영향을 조사하였고, 증식억제 현상이 apoptosis 유발 에 어떠한 영향을 미치는 지를 유전자 수준에서 조사한 결과 몇 가지 중요한 유전자들의 발현 변화에 대한 유의적인 결과 를 얻었기에 이를 보고하는 바이다.

\section{재료 및 방법}

\section{시료준비}

본 실험에 사용된 황금은 동의대학교 부속 한방병원에서 제공 받았으며, 에탄올 추출물(EESB)을 얻기 위하여 흐르는 물로 충분히 세척하고 건조시킨 후 잘게 분쇄하였다. 건조된 황금 $100 \mathrm{~g}$ 당 ethanol 1 를 첨가하여 $60^{\circ} \mathrm{C}, 150 \mathrm{rpm}$ 으로 3일
간 교반시킨 후 상층액만 분리하여 $3,000 \mathrm{rpm}$ 에서 20 분간 원 심분리 시켜 찌꺼기를 제거하였다. 찌꺼기가 제거된 EESB를 Whatman 필터(No. 2)를 이용하여 걸러내고 감압 농축과정을 통하여 고형성분을 얻은 다음 막자사발로 잘게 마쇄하고 밀봉 시켜 $-70^{\circ} \mathrm{C}$ 에 보관하였다. 실험 시에는 dimethyl sulfoxide (DMSO, Sigma-Aldrich Chemical Co., St. Louis, MO, USA)를 이용하여 $100 \mathrm{mg} / \mathrm{ml}$ 의 농도로 만든 다음 이를 적정 농도로 배지에 희석하여 처리하였다.

\section{실험재료}

단백질 발현 분석을 위하여 사용된 tumor necrosis factor (TNF)-related apoptosis-inducing ligand (TRAIL), death receptor 4 (DR4), DR5, Fas, Fas ligand (FasL), Bcl-2, Bcl- $\mathrm{X}_{\mathrm{L}}$, $\mathrm{Bax}, \mathrm{Bad}$, Bid, survivin, $\mathrm{X}$-linked inhibitor of apoptosis protein (XIAP), cellular inhibitor of apoptosis protein-1 (cIAP-1), cIAP-2, caspase-3, caspase-8, caspase-9, poly(ADP-ribose) polymerase (PARP), $\beta$-catenin, phospholipase $\mathrm{C}$ gamma-1 (PLCy-1) 및 actin 항체는 Santa Cruz Biotechnology Inc. (Santa Cruz, CA, USA)에서 구입하였으며, immunoblotting 을 위해 2차 항체로 사용된 horseradish peroxidase (HRP)conjugated anti-mouse 및 anti-rabbit 항체는 Amersham Life Science Corp. (Arlington Heights, IL, USA)에서 구입하였다. 또한 caspases의 in vitro 활성 측정을 위한 colorimetric assay kit는 R\&D Systems (Minneapolis, MN, USA)에서 구입하였 으며, caspases의 활성을 억제하기 위하여 사용된 pan-caspases inhibitor인 z-VED-fmk는 CalBiochem (San Diego, CA, USA)에서 구입하였다.

\section{세포배양 및 MTT assay에 의한 세포 증식억제 조사}

실험에 사용된 인체 신세포암 Caki-1 세포는 생명공학연구 소(KRIBB, Taejeon, Korea)에서 분양 받았으며 $90 \%$ 의 RPMI-1640 배지(Gibco-BRL, Grand Island, NY, USA), 10\%의 우태아혈청(fetal bovine serum, FBS) 및 $1 \%$ 의 penicillin 및 streptomycin (Gibco-BRL)이 포함된 성장배지를 사용하여 5\% $\mathrm{CO}_{2}, 37^{\circ} \mathrm{C}$ 의 조건하에서 배양하였다. 부유시킨 다음 적정 수 의 세포를 분주하여 재배양하였다. EESB 처리에 의한 증식억 제의 정도를 확인하기 위하여 MTT assay를 이용하였다. 먼저 Caki-1 세포에 적정농도의 EESB를 처리하고 48시간 동안 배 양한 후 배지를 제거하고 tetrazolium bromide salt (MTT, Sigma-Aldrich)를 $0.5 \mathrm{mg} / \mathrm{ml}$ 농도로 희석하여 $200 \mu \mathrm{l}$ 씩 분주 하고 $37^{\circ} \mathrm{C}$ 에서 3 시간 동안 다시 배양하였다. 배양이 끝난 다음 MTT 시약을 제거하고 DMSO를 $1 \mathrm{ml}$ 씩 분주하여 well에 생성 된 formazin을 모두 녹인 후 96 well plate에 $200 \mu \mathrm{ll}$ 씩 옮겨서 ELISA reader (Molecular Devices, Sunnyvale, CA, USA)로 $540 \mathrm{~nm}$ 에서 흡광도를 측정하였다. 


\section{DAPI staining에 의한 세포핵의 형태 관찰}

EESB가 처리된 세포를 모은 다음 $2,000 \mathrm{rpm}$ 으로 5 분간 원 심 분리하여 상층액을 제거하고 $37 \%$ formaldehyde 용액과 PBS를 $1: 9$ 의 비율로 섞은 fixing solution을 모아진 세포에 $500 \mathrm{pl}$ 첨가하여 상온에서 10 분 동안 고정하였다. 고정된 세포 를 2,000 rpm으로 5분간 원심 분리하여 fixing solution을 제거 하고 PBS $200 \mu 1$ 에 부유시킨 후 세포가 포함되어 있는 PBS $80 \mu 1$ 를 slide glass 위에 떨어뜨리고 $1,000 \mathrm{rpm}$ 에서 5 분간 cytospin하여 세포를 slide glass에 부착하였다. 세포가 부착된 slide glass를 $\mathrm{PBS}$ 로 2 3회 정도 세척하고 $\mathrm{PBS}$ 가 마르기 전에 $0.2 \%$ 의 Triton X-100 (Amresco, Solon, OH, USA)을 첨가하여 상온에서 10 분간 고정한 후 $2.5 \mu \mathrm{g} / \mathrm{ml}$ 농도의 $4^{\prime}, 6$-diamidino-2-phenylindole (DAPI, Sigma-Aldrich) 용액을 처리 하여 상온에서 15분간 염색하였다. 염색이 끝난 후 DAPI 용액 을 충분하게 세척하고 mounting solution을 처리한 후 형광 현미경(fluorescene microscope, Carl Zeiss, Germany)을 이용 하여 400 배의 배율로 각 농도에 따른 암세포의 핵의 형태 변화 를 관찰하였다.

\section{DNA 단편화 분석}

준비된 세포들을 모은 다음 $2,000 \mathrm{rpm}$ 으로 5 분간 원심 분리 하여 상층액을 제거하였다. 상층액이 제거된 세포에 $850 \mu 1$ 의 lysis buffer [5 mM Tris-HCl (pH 7.5), 5 mM EDTA, 0.5\% Triton X-100]를 첨가하여 상온에서 1시간 동안 lysis 시킨 다 음 $14,000 \mathrm{rpm}, 4^{\circ} \mathrm{C}$ 에서 20 분간 원심 분리하여 찌꺼기가 제거 된 상층액 $750 \mu 1$ 를 회수하였다. 회수된 상층액에 proteinase K solution (Sigma-Aldrich)을 $0.5 \mathrm{mg} / \mathrm{ml}$ 의 농도로 처리하여 $50^{\circ} \mathrm{C}$ 에서 3 시간 동안 반응시킨 후 $750 \mu \mathrm{l}$ 의 phenol : chloroform : isoamyl alcohol 혼합 용액(25: $24: 1$, Sigma-Aldrich)을 첨가하고 30 분간 회전교반 시킨 다음 $14,000 \mathrm{rpm}$ 에서 10 분간 원심 분리하였다. 여기서 얻어진 상층액 $600 \mu \mathrm{l}$ 에 $300 \mu \mathrm{l}$ 의 isopropanol (Sigma-Aldrich)과 $100 \mu \mathrm{l}$ 의 $5 \mathrm{M} \mathrm{NaCl}$ 를 첨가하여 $4^{\circ} \mathrm{C}$ 에서 24 시간 동안 반응시킨 후, $14,000 \mathrm{rpm}, 4^{\circ} \mathrm{C}$ 에서 30 분 간 원심 분리시켜 상층액을 제거하고 DNA pellet을 추출하였 다. DNA pellet에 RNase A가 적당량 들어있는 TE buffer를 이용하여 녹인 후, 6X gel loading dye (Bioneer, Daejeon, Korea)를 섞어 주었다. 마지막으로 $1.6 \%$ agarose gel을 만들어 서 1시간 동안 $50 \mathrm{~V}$ 로 전기영동 시킨 후 ethidium bromide (EtBr, Sigma-Aldrich)로 염색하여 DNA 단편화 현상을 확인 하였다.

\section{Flow cytometry 분석}

Caki-1 세포에서 EESB가 유발하는 apoptosis 정도를 정량 적으로 분석하기 위하여 정상 및 $\mathrm{EESB}$ 가 48 시간 동안 처리된 세포들을 모은 다음 $2,000 \mathrm{rpm}$ 으로 5 분간 원심분리하여 상층 액을 제거한 후 $\mathrm{PBS}$ 를 이용하여 2 3회 정도 세척하였다. 준
비된 세포는 CycleTEST PLUS DNA REAGENT Kit (Becton Dickinson, San Jose, CA, USA)를 이용하여 고정 및 염색을 하여 $4^{\circ} \mathrm{C}$, 암실에서 30 분 동안 반응을 시켰다. 반응시킨 세포 를 35-mm mesh를 이용하여 단일세포로 분리한 후 FACSCalibur (Becton Dickinson)를 적용시켜 분석하였다.

\section{Mitochondrial membrane potential (MMP, $\Delta \psi m)$ 의 분석}

$\mathrm{MMP}$ 변화 정도를 측정하기 위하여 적정시간 동안 $\mathrm{EESB}$ 가 처리된 세포들을 모은 다음 $500 \mu \mathrm{l}$ 의 $\mathrm{PBS}$ 를 첨가하여 충분히

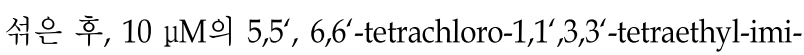
dacarbocyanine iodide (JC-1, Sigma-Aldrich) 용액을 처리하 여 20 분 동안 $37^{\circ} \mathrm{C}$ 에서 반응시켰다. 반응시킨 세포를 2,000 $\mathrm{rpm}$ 으로 원심 분리하여 상층액을 버리고 다시 $500 \mu \mathrm{l}$ 의 차가 운 $\mathrm{PBS}$ 를 첨가하고 $35 \mathrm{~mm}$ mesh를 이용하여 단일세포로 분리 한 후 FACSCalibur에 적용시켜 ENIS 처리에 따른 MMP의 변화 정도를 분석하였다.

\section{Western blot analysis에 의한 단백질 발현의 분석}

준비된 세포에 적당량의 lysis buffer $[25 \mathrm{mM}$ Tris-Cl $(\mathrm{pH}$ 7.5), $250 \mathrm{mM} \mathrm{NaCl}, 5 \mathrm{mM}$ EDTA, 1\% NP-40, $1 \mathrm{mM}$ phenymethylsulfonyl fluoride (PMSF), $5 \mathrm{mM}$ dithiothreitol (DTT)]를 첨가하여 $4^{\circ} \mathrm{C}$ 에서 1 시간 동안 반응시킨 후, $14,000 \mathrm{rpm}$ 으로 30 분간 원심 분리하여 상층액에 있는 총 단백질을 분리하였 다. 상층액의 단백질 농도는 Bio-Rad 단백질 정량 시약 (Bio-Rad, Hercules, CA, USA)과 그 사용방법에 따라 정량 한 다음 동량의 Laemmli sample buffer (Bio-Rad)를 섞어서 sample을 만들었다. 동량의 sample을 sodium dodecyl sulphate (SDS)-polyacrylamide gel을 이용하여 전기영동으로 분리한 후, nitrocellulose membrane (Schleicher and Schuell, Keene, $\mathrm{NH}, \mathrm{USA}$ )으로 electroblotting에 의해 전이시켰다. 분리된 단 백질이 전이된 nitrocellulose membrane을 $5 \%$ skim milk를 처리하여 비특이적인 단백질들에 대한 blocking을 실시하고 1 차 항체를 처리하여 상온에서 2 시간 이상 또는 $4^{\circ} \mathrm{C}$ 에서 over night 시킨 다음 PBS-T로 세척하고 처리된 1차 항체에 맞는 2 차 항체를 사용하여 상온에서 1 시간 정도 반응시켰다. 반응 이 끝난 후 암실에서 enhanced chemiluminoesence (ECL) solution (Amersham Life Science Corp.)을 적용시킨 다음 X-ray film에 감광시켜 특정단백질의 발현양을 분석하였다.

\section{In vitro caspases activity 측정}

Apoptosis 유발에 있어서 중요한 작용을 하는 것으로 알려 진 caspases의 활성 정도가 EESB 처리에 의하여 어떠한 변화 를 유발하는지 알아보기 위하여 정상 및 EESB가 처리된 배지 에서 48 시간 배양된 세포를 모은 뒤 상기와 동일한 방법으로 단백질을 추출하고 정량하였다. $150 \mu \mathrm{g}$ 의 단백질이 함유된 50 
$\mu \mathrm{l}$ 의 sample에 기질 $100 \mu \mathrm{M}$ 이 함유된 reaction buffer [40 mM HEPES (pH 7.4), 20\% glycerol (v/v), 1 mM EDTA, 0.2\% NP-40 and $10 \mathrm{mM} \mathrm{DL-DTT]} 50 \mu \mathrm{l}$ 를 혼합하여 각 sample 당 총 volume이 $100 \mu 1$ 가 되게 하였다. 여기에 caspases 종류에 따른 기질 $5 \mu 1$ 를 첨가하여 $37^{\circ} \mathrm{C}$, 암실에서 3 시간 동안 반응시 킨 후 ELISA reader를 이용하여 $405 \mathrm{~nm}$ 의 흡광도를 이용하여 반응의 정도를 측정하였다. 실험에 사용된 기질은 caspase-3의 경우에는 Asp-Glu-Val-Asp (DEVD)-p-nitroaniline (pNA)이 었고 caspase-8의 경우에는 Ile-Glu-Thr-Asp (IETD)-pNA이었 으며, caspase-9은 Leu-Glu-His-Asp (LEHD)-pNA였다.

\section{결 과}

\section{Caki-1 세포의 증식에 미치는 EESB의 영향}

인체 신세포암 Caki-1 세포에서 EESB가 유발하는 증식억 제 현상을 조사하기 위하여 $\mathrm{EESB}$ 를 적정농도로 48시간 동안 처리한 후, MTT assay를 실시하였다. Fig. 1에 나타낸 바와 같이 EESB 처리군의 경우에는 $0.1 \mathrm{mg} / \mathrm{ml}$ 농도까지는 큰 변 화가 나타나지 않았지만 $0.2 \mathrm{mg} / \mathrm{ml}$ 처리군에서부터 증식억 제 현상이 나타나기 시작하여 $0.8 \mathrm{mg} / \mathrm{ml}$ 및 $1 \mathrm{mg} / \mathrm{ml}$ 처리군 에서 각각 약 $72 \%$ 및 $80 \%$ 의 증식억제 효과가 있는 것으로 나타났다.

\section{핵의 형태변화에 미치는 $\mathrm{EESB}$ 의 영향}

EESB 처리에 의한 Caki-1 세포의 증식억제가 apoptosis 유 발 시 특이하게 관찰되는 핵의 형태변화와 어떠한 연관이 있 는지를 확인하기 위하여 EESB가 처리된 배지에서 48시간 동

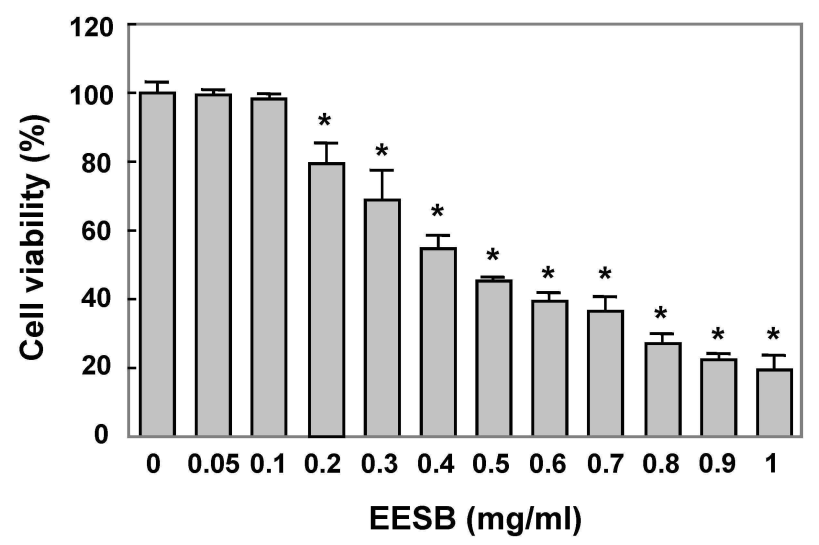

Fig. 1. Inhibition of cell growth of human renal cell carcinoma Caki-1 cells after treatment with ethanol extract of $S$. baicalensis (EESB). Cells were seeded at $1 \times 10^{5} / \mathrm{ml}$ in a 6-well plate and treated with variable concentrations of EESB for $48 \mathrm{hr}$. The growth inhibition was measured by the metabolic-bye-based MTT assay. The data shown are means \pm SD of three independent experiments. The statistical significance of the results was analyzed by Student's t-test $\left({ }^{*}, p<0.05\right.$ vs. untreated control).
안 배양된 암세포를 고정시킨 후 핵산에 특이적으로 결합하는 형광물질인 DAPI 염색을 실시하여 형광현미경하에서 관찰하 였다. Fig. $2 \mathrm{~A}$ 에 나타낸 바와 같이 EESB가 처리되지 않은 정상 배지에서 자란 암세포에서 핵의 형태가 뚜렷하게 정상으로 염색이 되었으나 $\mathrm{EESB}$ 처리농도 증가에 따라 전체적인 핵의 밀도 감소와 더불어 apoptosis가 일어난 세포에서 전형적으로 관찰되는 염색질 응축에 의한 apoptotic body가 관찰되었다.

\section{Apoptosis 유발에 미치는 EESB의 영향}

Caki-1 세포에서 EESB 처리에 의한 apoptosis 유발에 관한 추가적인 증거를 제시하기 위하여 먼저 상기와 동일한 조건으 로 배양된 암세포를 대상으로 DNA flow cytometry를 이용하 여 apoptosis가 유발되었을 것으로 예상되는 sub-G1기에 해당 하는 세포를 측정한 결과는 $\mathrm{Fig} .2 \mathrm{C}$ 에 나타낸 바와 같다. 결과 에서 알 수 있듯이 정상배지에서 자란 암세포에서 자연적 apoptosis 유발 빈도는 약 7.05\%로 매우 낮았으나 EESB 처리 농도 증가에 따라 sub-G1기에 해당하는 세포의 빈도가 증가하 여 $0.4,0.6$ 및 $0.8 \mathrm{mg} / \mathrm{ml}$ 처리군에서 약 $31.35,49.68$ 및 $68.14 \%$ 정도의 apoptosis가 유발되었다.

다음으로 apoptosis 유발의 또 다른 증거인 DNA 단편화 현상을 관찰하였다. DNA 단편화 현상은 endonuclease가 활 성화되어 chromosomal DNA가 단편화됨으로서 나타나는 현 상으로서 apoptosis가 일어난 세포들에서 나타나는 전형적인 현상으로 알려져 있다. 이를 위하여 정상 및 EESB가 함유된 배지에서 자란 암세포를 대상으로 총 DNA를 추출하여 agarose gel 전기영동으로 조사한 결과는 Fig. 2B에 나타난 바와 같다. 결과에서 볼 수 있듯이 $\mathrm{EESB} 0.2 \mathrm{mg} / \mathrm{ml}$ 처리군까지는 DNA 단편화 현상이 나타나지 않았지만 $0.4 \mathrm{mg} / \mathrm{ml}$ 처리군에 서 약한 DNA 단편화 현상이 관찰되기 시작하여 $0.6 \mathrm{mg} / \mathrm{ml}$ 처리군에서부터 DNA 단편화 현상이 강하게 나타나는 것으로 조사되었다. 이상의 결과를 살펴볼 때 인체 신세포암 Caki-1 세포에서 EESB 처리에 의한 증식억제는 apoptosis 유발과 밀 접한 연관이 있음을 알 수 있었다.

\section{$\mathrm{MMP}(\Delta \psi m)$ 에 미치는 $\mathrm{EESB}$ 의 영향}

EESB 처리에 따른 apoptosis 유발에 있어서 미토콘드리아 가 어떠한 역할을 하는지를 확인하기 위하여 미토콘드리아 막 전위(MMP, $\left.\Delta \psi_{m}\right)$ 를 조사한 결과는 Fig. 3 에 나타난 바와 같다. 정상 및 $\mathrm{EESB}$ 가 처리된 Caki-1 세포의 $\mathrm{MMP}$ 손실 정도 를 dual-emission fluorescent dye인 JC-1을 이용하여 확인한 결과 정상 배지에서 자란 세포의 경우에는 정상적인 $\mathrm{MMP}$ 를 가진 세포는 약 $78.5 \%$, 손상된 $\mathrm{MMP}$ 를 가진 세포는 약 $21.5 \%$ 로 나타났지만 $\mathrm{EESB}$ 처리농도 증가에 따라서 $\mathrm{MMP}$ 손실 정도 가 증가하였으며, 최고 농도인 $0.8 \mathrm{mg} / \mathrm{ml}$ 처리군에서는 약 $91.6 \%$ 정도의 세포에서 $\mathrm{MMP}$ 의 손실이 유발되는 것으로 나타 났다. 이는 EESB 처리에 의한 Caki-1 세포의 apoptosis 유발은 
A

$\operatorname{EESB}(\mathrm{mg} / \mathrm{ml})$

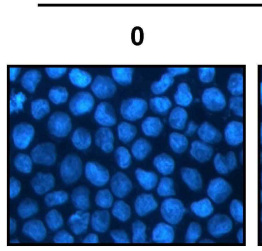

0.2

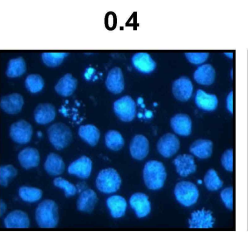

0.6

0.8
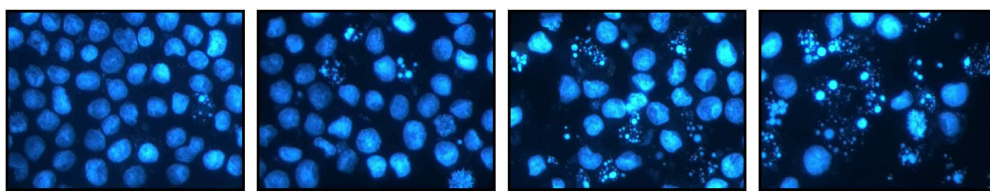

B

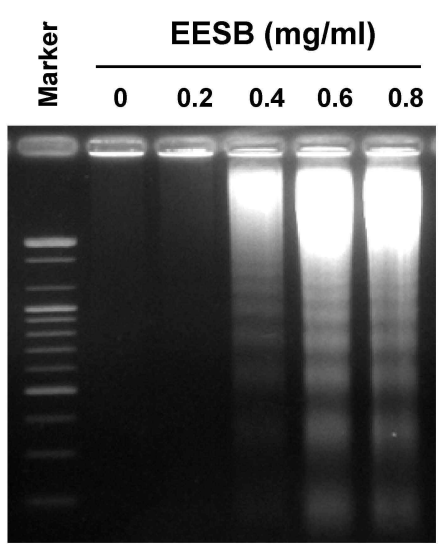

C

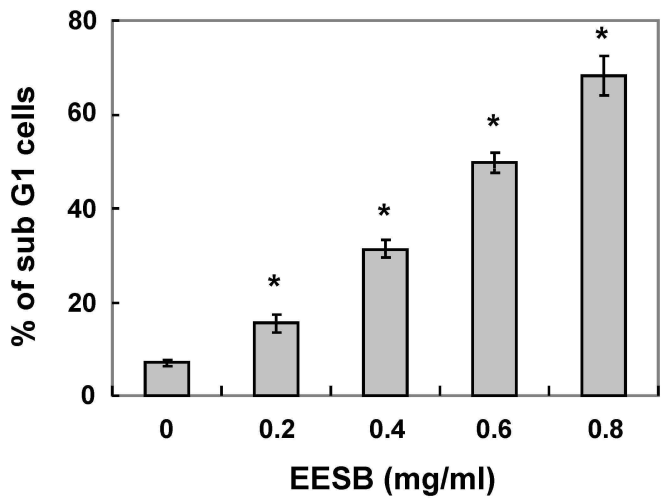

Fig. 2. Induction of apoptosis by EESB treatment in Caki-1 cells. (A) To investigate the morphological changes of nuclei and apoptotic body formation, cells were treated with various concentrations of EESB for $48 \mathrm{hr}$ and stained with DAPI solution. Stained nuclei were then observed under fluorescent microscope using a blue filter. Magnification, X400. (B) For the analysis of DNA fragmentation, genomic DNA from cells grown under the same conditions as (A) was extracted, separated by $1.6 \%$ agarose gel electrophoresis, and visualized under UV light after staining with EtBr. Marker indicates a size marker of the DNA ladder. (C) To quantify the degree of EESB-induced apoptosis, the sub-G1 population was evaluated using a flow cytometer. The results are expressed as the mean $\pm \mathrm{SD}$ of three independent experiments. The statistical significance of the results was analyzed by Student's t-test $\left({ }^{*}, p<0.05\right.$ vs. untreated control).

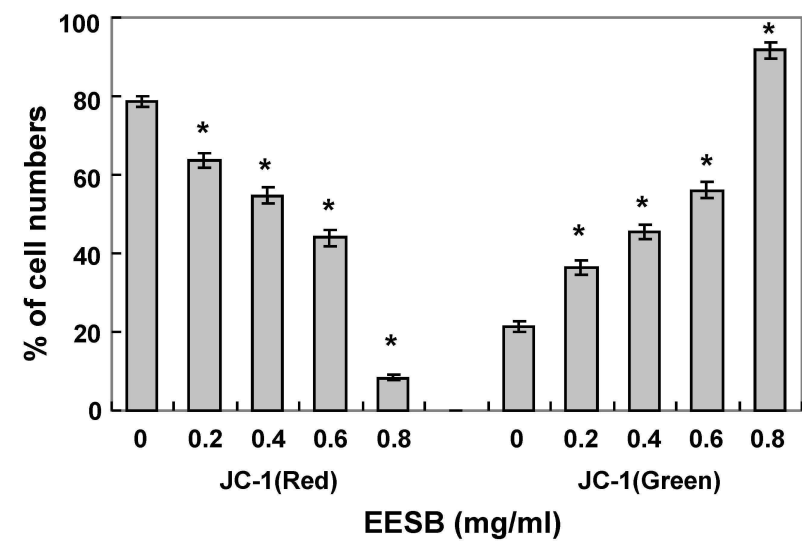

Fig. 3. Effects of EESB treatment on mitochondrial membrane potential (MMP, $\left.\Delta \psi_{m}\right)$ in Caki-1 cells. Cells were treated with various concentrations of EESB for $48 \mathrm{hr}$. Then MEEL treated cells were incubated with JC-1 dye (10 $\mu \mathrm{M})$ for $30 \mathrm{~min}$ in the dark and the loss of MMP was measured by flow cytometry. Each point represents the mean \pm SD of three separate experiments. The statistical significance of the results was analyzed by Student's t-test $\left({ }^{*}, p<0.05\right.$ vs. untreated control).
$\mathrm{MMP}$ 교란을 통한 미토콘드리아 기능 손상이 관여하고 있음 을 보여주는 것이다.

\section{Death receptor 및 ligand의 발현에 미치는 EESB의 영향}

Apoptosis 유발 과정에서 extrinsic pathway를 경유하는 과 정에서 중요한 역할을 하는 death receptor 및 ligand에 속하 는 유전자들의 발현에 EESB가 어떠한 영향을 미치는지를 확 인한 결과는 Fig. 4 에 나타난 바와 같다. 결과에서 알 수 있듯이 death receptor에 속하는 여러 유전자 중 DR5 및 Fas는 큰 변화가 관찰되지 않았지만 DR4의 발현이 증가하는 것으로 나 타났으며, death ligand에 속하는 유전자 중에서는 TRAIL의 변화는 관찰되지 않았지만 FasL의 발현이 EESB 처리 농도 의 존적으로 증가하였다. 이는 $\mathrm{EESB}$ 의 처리에 의한 Caki-1 세포 에서의 apoptosis 유발에 있어서 death receptor 및 ligand의 발현 변화에 따른 extrinsic pathway가 관여한다는 것을 보여 주는 결과이다.

\section{$\mathrm{Bcl}-2$ family의 발현에 미치는 $\mathrm{EESB}$ 의 영향}

다음으로 intrinsic pathway에 있어서 중요한 역할을 하는 


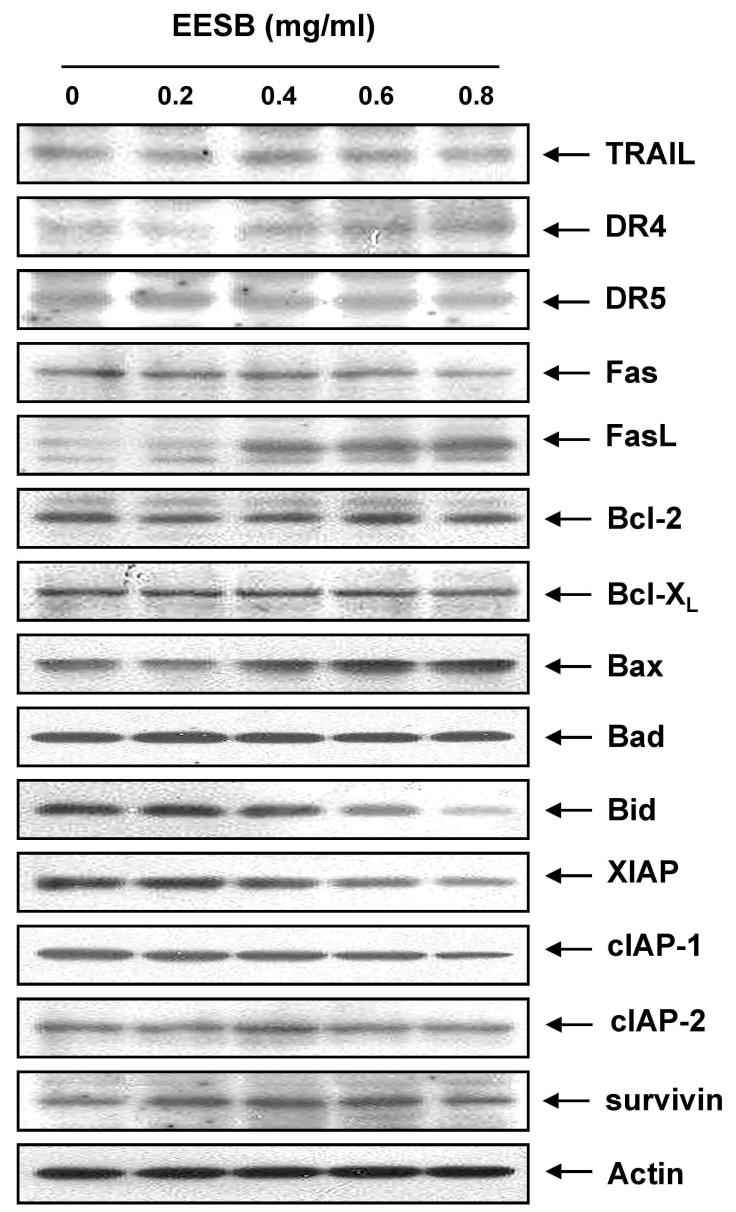

Fig. 4. Expression levels of apoptosis-related proteins by EESB treatment in Caki-1 cells. Cells were treated with the indicated concentrations of EESB for $48 \mathrm{hr}$. The cells were lysed and then equal amounts of cell lysates were separated on SDS-polyacrylamide gels and transferred to PVDF membranes. The membranes were probed with the indicated antibodies and the proteins were visualized using an ECL detection system. Actin was used as an internal control.

것으로 알려진 Bcl-2 family 유전자의 발현에 EESB가 어떠한 영향을 미치는지를 확인한 결과(Fig. 4), apoptosis를 억제하 는 것으로 알려진 anti-apoptotic 유전자인 Bcl-2 및 Bcl- $\mathrm{X}_{\mathrm{L}}$ 의 경우는 큰 변화가 나타나지 않았지만 apoptosis를 유발하는 것으로 알려진 pro-apoptotic 유전자인 Bax의 경우는 EESB 처리에 의하여 농도 의존적으로 증가하는 것으로 나타났다. 또한 활성화된 caspase-8에 의하여 단편화되어 $\mathrm{MMP}$ 손실 유발에 중요한 역할을 하는 것으로 알려진 $\mathrm{Bid}$ 단백질의 경 우에도 EESB 처리에 의하여 total Bid의 발현이 감소하는 것 으로 나타났으므로 단편화된 형태인 $\mathrm{tBid}$ 의 증가가 유발되었 다는 것을 예상할 수 있었다. 이는 EESB 처리에 의한 apoptosis 유발에는 Bcl-2 family가 중요한 역할을 하고 있으며,
특히 $\mathrm{Bax}$ 의 발현증가와 함께 $\mathrm{Bid}$ 의 단편화로 인한 미토콘드 리아 기능 이상에 따른 intrinsic pathway도 관여한다는 것을 보여주는 결과이다.

\section{IAP family의 발현에 미치는 EESB의 영향}

Apoptosis에 관여하는 여러 인자들 중 caspase와 직접적으 로 결합하여 caspase의 활성을 억제함으로서 apoptosis 유발 을 억제하는 것으로 알려진 inhibitors of apoptosis protein (IAP) family에 속하는 인자들의 발현에 EESB가 어떠한 영향 을 미치는 지를 확인하였다. Fig. 4 에 나타난 바와 같이 EESB 처리에 의하여 CIAP-1 및 survivin의 발현에는 큰 변화가 나타 나지 않았지만 XIAP 및 $\mathrm{CIAP}-1$ 의 발현은 $\mathrm{EESB}$ 농도 의존적으 로 감소하였음을 알 수 있었다.

\section{Caspases의 발현 및 활성에 미치는 EESB의 영향}

Apoptosis 유발에 중요한 조절인자로서 작용하는 것으로 알려진 caspases 중 extrinsic 및 intrinsic pathway에 직접적 으로 관여하는 caspase-3, -8 및 -9의 발현 및 활성에 미치는 $\mathrm{EESB}$ 의 영향을 조사하였다. 먼저 Fig. $5 \mathrm{~A}$ 의 결과에서 볼 수 있듯이 EESB 처리에 의하여 불활성형인 pro-caspase-3, -8 및 -9 단백질의 발현은 $\mathrm{EESB}$ 처리 농도의존적으로 감소되었으 나 뚜렷한 활성형의 단백질 발현 증가를 정확히 관찰하기는 어려웠다. 따라서 in vitro caspases activity assay를 통하여 이들 caspase의 활성 정도를 직접 분석한 결과, Fig. $5 \mathrm{~B}$ 에서 나타난 바와 같이 EESB 처리에 의하여 caspase-3, -8 및 -9의 활성이 처리 농도 의존적으로 증가하여 $0.8 \mathrm{mg} / \mathrm{ml}$ 처리군에 서는 각각 4.17 배, 2.73 배 및 2.21 배 증가하는 것으로 나타났 다. 또한 활성화된 caspase-3에 의하여 특이하게 분해가 일어 나서 apoptosis 유발에 직접적으로 관여하는 것으로 알려진 몇 가지 표적 단백질의 발현에 미치는 $\mathrm{EESB}$ 의 영향을 조사한 결과는 Fig. $5 \mathrm{~A}$ 에 나타난 바와 같다. 결과에서 볼 수 있듯이 EESB 처리에 의하여 DNA repair와 genomic stability에 관여 하는 PARP, 세포 내 골격 유지와 부착성 세포의 전사 조절에 중요한 역할을 하는 $\beta$-catenin 및 세포의 성장과 증식에 중요 한 역할을 하는 PLC- 81 의 발현의 감소와 함께 단편화 현상이 관찰되었다.

\section{Caspase 활성 억제를 통한 apoptosis의 억제}

이상의 결과에서 EESB 처리에 따른 Caki-1 세포의 apoptosis 유발에 caspase의 활성화가 중요한 역할을 하는 것으로 나타났으므로 caspase의 활성을 억제하였을 경우에 apoptosis 가 억제되는 지를 확인하였다. 먼저 핵의 형태 및 sub-G1 유발 정도를 관찰한 결과, Fig. $6 \mathrm{~A}$ 및 $\mathrm{B}$ 에서 나타난 바와 같이 $\mathrm{EESB}$ 처리에 의하여 증가된 apoptotic body 및 sub-G1이 pan-caspases inhibitor인 z-VED-fmk 선처리에 의하여 유의적으로 억 제되는 것으로 나타났다. 또한 EESB에 의한 Caki-1 세포의 증 


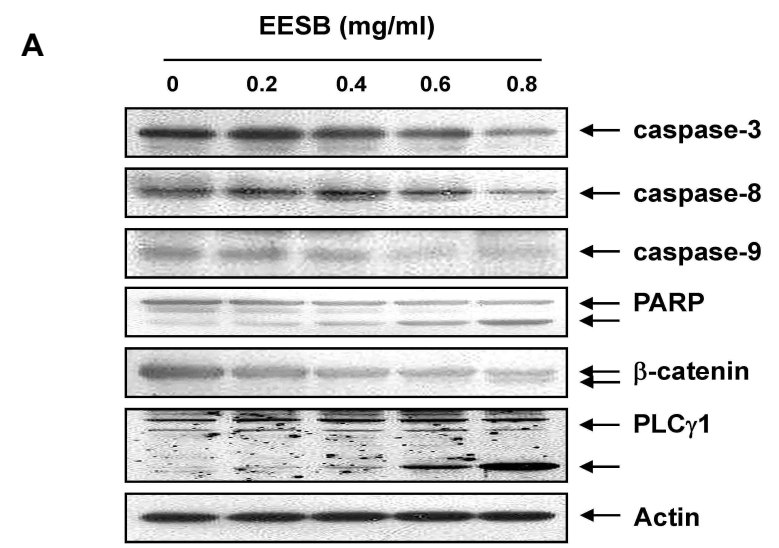

B

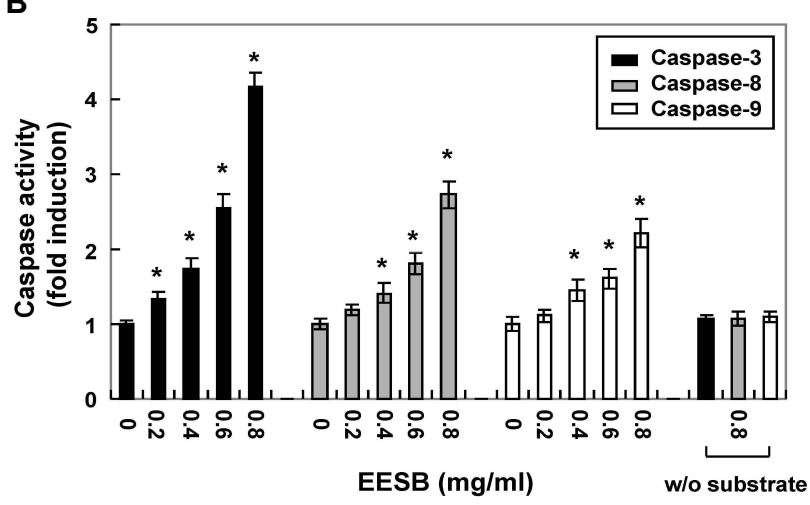

Fig. 5. Activation of caspases and the degradation of the PARP, PLC- $\gamma 1$ and $\beta$-catenin protein by EESB treatment in Caki-1 cells. (A) Cells were incubated with various concentrations of EESB for $48 \mathrm{hr}$, lysed and cellular proteins were separated by SDS-polyacrylamide gels and transferred onto nitrocellulose membranes. The membranes were probed with indicated antibodies. Proteins were visualized using ECL detection system. Actin was used as a loading control. (B) After $48 \mathrm{hr}$ incubation with EESB, aliquots (150 $\mu \mathrm{g}$ protein) were incubated with substrates, DEVD-pNA, IETD-pNA and LEHD-pNA, for in vitro caspase-3, -8 and -9 activity, respectively, at $37^{\circ} \mathrm{C}$ for $3 \mathrm{hr}$. The released fluorescent products were measured. Results are expressed as the means \pm S.E. of three independent experiments. The statistical significance of the results was analyzed by Student's t-test $\left({ }^{*}, p<0.05\right.$ vs. untreated control).

식억제가 z-VED-fmk에 의하여 회복되는지를 확인한 결과, Fig. 6C에 나타난 바와 같이 EESB 단독 처리군에 비교하여 현저하게 회복되는 것으로 나타났다. 마지막으로 $\mathrm{EESB}$ 에 의 하여 유발된 DNA 단편화 현상의 경우도 $\mathrm{z}-\mathrm{VED}-\mathrm{fmk}$ 선처리 에 의하여 현저하게 억제되는 것으로 나타났다(Fig. 6D).

\section{고 찰}

본 연구에서는 다양한 약리학적 활성을 가지는 것으로 알려
진 황금의 항암효능을 알아보기 위하여 인체 신세포암 Caki-1 세포의 생존율 및 증식에 미치는 영향과 이와 연관된 apoptosis 유발 여부와 함께 그에 따른 분자생물학적 기전에 대해서 조사하였다. 이를 위하여 황금 에탄올 추출물(EESB)의 처리에 따른 증식억제 정도를 조사한 결과, $\mathrm{EESB}$ 처리 농도의존적으 로 나타나는 증식억제 현상은 apoptosis 유발과 밀접한 관련 이 있었다.

일반적으로 apoptosis 과정은 extrinsic 및 intrinsic pathway로 구분되며, 이 과정들은 death receptors, Bcl-2 family 및 caspases 등과 같은 여러 유전자들이 관여하는 것으로 알려 져 있다. Extrinsic pathway의 경우는 세포막에 존재하는 DR4, DR5 및 Fas 등과 같은 death receptor에 TRAIL 및 FasL 등과 같은 apoptotic ligand가 결합함으로서 시작된다[26, 41, 46]. Death receptors가 활성화되면 initiator caspase인 caspase-8 의 활성화에 의한 caspase cascade에 의하여 하위 단계에 있는 caspase-3의 활성화에 직접적으로 관여하거나 $\mathrm{Bid}$ 를 단편화시 킴으로서 $\mathrm{tBid}$ 를 형성하여 intrinsic pathway를 통한 apoptosis를 증폭시키는 것으로 알려져 있다 $[29,33]$. 또 다른 apoptosis 과정인 intrinsic pathway는 $\mathrm{UV}$, 방사선, DNA 손상 및 많은 chemotherapeutic agent 등과 같은 여러 가지 자극에 의 하여 미토콘드리아의 기능 이상이 동반된다. Bcl-2 family는 구조적으로 네 가지의 $\mathrm{Bcl}$ homology $(\mathrm{BH})$ domains $(\mathrm{BH} 1-$ $\mathrm{BH} 4)$ 중 최소한 한 개의 domain을 포함하고 있으며, mitochondria 외막에서 mitochondria 보존과 mitochondria에 의해 유도되는 apoptosis를 조절하는 intrinsic pathway의 중 요한 조절자이다[12, 49]. Bcl-2 family는 Bcl-2, Bcl-xL, Bcl-w 및 $\mathrm{Mcl}-1$ 과 같이 apoptosis를 억제하는 anti-apoptotic member와 $\mathrm{Bax}, \mathrm{Bad}, \mathrm{Bak}, \mathrm{Bid}$ 및 $\mathrm{Bcl}-\mathrm{x}$ 과 같이 apoptosis를 유발하 는 pro-apoptotic member로 구성되어 있으며, 이들은 서로 dimer를 형성하며 결합하고 있다[49]. 하지만 anti-apoptotic 및 pro-apoptotic member들 사이의 균형이 깨어지게 되면 미 토콘드리아의 기능 이상을 유발하게 되고 미토콘드리아로 내 막에 존재하고 있는 cytochrome $c$ 와 같은 단백질인 세포질로 방출됨으로서 하위단계에 있는 여러 가지 유전자들을 조절하 여 apoptosis가 유발되는 것으로 알려져 있다[2, 11, 43]. 따라 서 EESB 처리에 따른 Caki-1 세포에서의 apoptosis 유발에 있 어서 미토콘드리아 기능 손상이 관여하는 지를 확인하기 위하 여 $\mathrm{MMP}$ 의 변화 정도를 확인한 결과, $\mathrm{EESB}$ 처리 농도 증가에 따라 $\mathrm{MMP}$ 의 손실이 증가하는 것을 관찰할 수 있었다(Fig. 3). 이러한 $\mathrm{MMP}$ 의 손실에 extrinsic pathway가 관여하는 지를 확인하기 위하여 death receptor 및 apoptotic ligand 유전자들 의 발현 변화를 확인한 결과, DR4 및 FasL의 발현이 증가하는 것으로 관찰되었다(Fig. 4). 또한 intrinsic pathway에 관여하 는 Bcl-2 family 유전자들의 발현변화를 확인한 결과, pro-apoptotic 유전자인 $\mathrm{Bax}$ 의 발현증가와 함께 $\mathrm{Bid}$ 단백질의 발현감소가 나타났으므로 상대적으로 $\mathrm{tBID}$ 의 생성이 증가되 
A

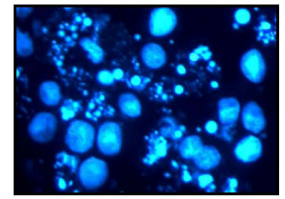

$+$

$+\quad$ z-VED-fmk $(50 \mu \mathrm{M})$

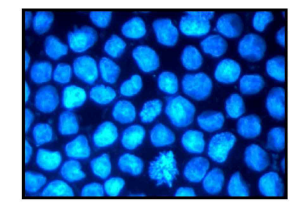

$-$

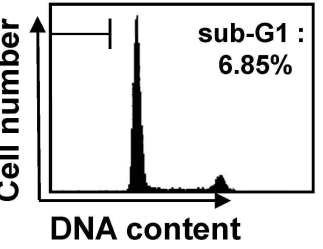

DNA content
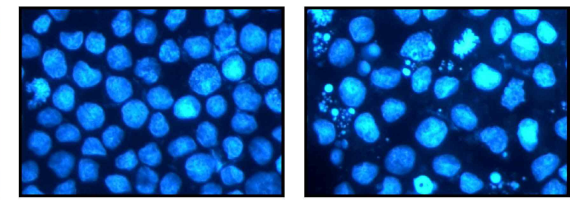

B
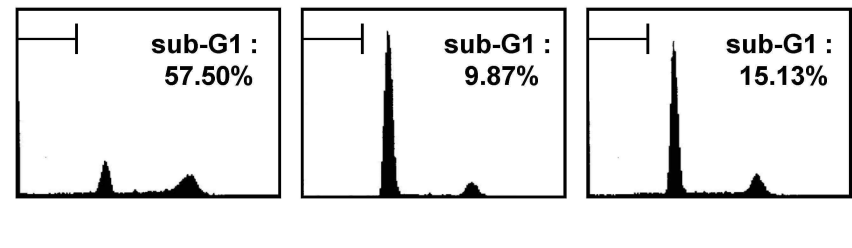

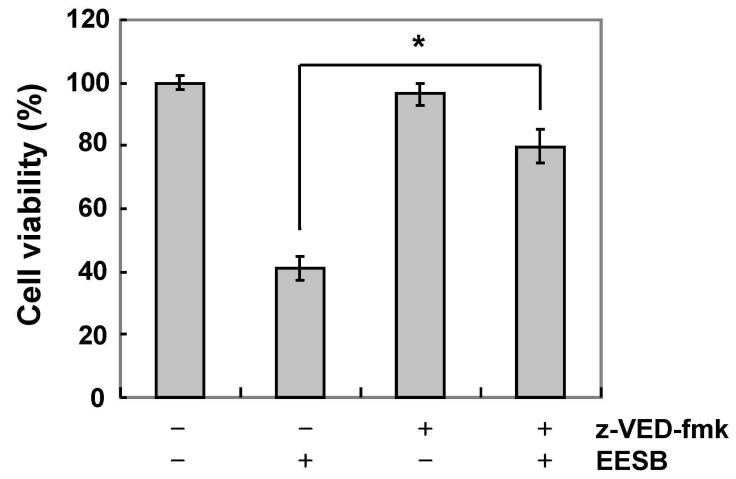

D
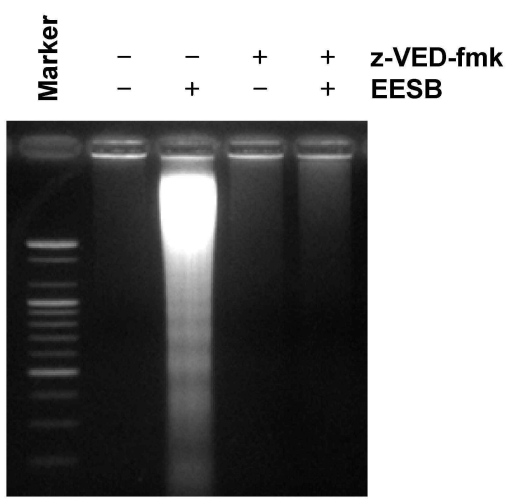

Fig. 6. Inhibition of EESB-induced apoptosis by the pan-caspase inhibitor in Caki-1 cells. Cells were pretreated for $1 \mathrm{hr}$ with or without z-VED-fmk $(50 \mu \mathrm{M})$, and then with EESB $(0.6 \mathrm{mg} / \mathrm{ml})$ for an additional $48 \mathrm{hr}$. (A) The cells were stained with DAPI for $10 \mathrm{~min}$ and photographed with a fluorescence microscope using a blue filter. Magnification, $\times 400$. (B) The cells were fixed and stained with PI, and analyzed by flow cytometry. The percentages of cells with hypodiploid DNA (sub-G1 phase) contents represent the fractions undergoing apoptotic DNA degradation. Data are means average of two separate experiments. (C) The growth inhibition was measured by the metabolic-bye-based MTT assay. Results are expressed as percentage of the vehicle treated control $\pm \mathrm{SD}$ of three separate experiments. The statistical significance of the results was analyzed by Student's t-test $\left({ }^{*}, p<0.05\right.$ vs. untreated control). (D) DNA fragmentation was analyzed by extracting the fragmented DNA and separating it by electrophoresis in a $1.6 \%$ agarose gel containing EtBr.

었다는 것을 알 수 있었다(Fig. 5). 이상의 결과에서 인체 신세 포암인 Caki-1 세포에서 EESB에 의한 apoptosis 유발은 death receptor 및 apoptotic ligand의 발현변화에 따른 truncated $\operatorname{Bid}$ (tBID)의 생성증가와 Bcl-2 family 유전자들의 발현변화에 의하여 미토콘드리아의 기능 이상이 유발되어 미토콘드리아 내막에 존재하고 있는 cytochrome 가 세포질로 방출되면서 개시하는 것으로 생각되어 진다.

IAP family는 apoptosis에 중요한 역할을 하는 것으로 알려 진 caspase와 직, 간접적으로 결합함으로서 caspase의 활성을 억제하여 apoptosis를 억제하는 것으로 알려져 있다[10, 45]. IAP family중 일부는 caspase의 ubiquitination 및 degradation을 조절하는 RING finger domain을 가지며, 또 다른 일부 는 protein - protein interaction 기능을 하는 caspase-recruitment domain (CARD)을 가지는 것으로 알려져 있다[6]. IAP family 중 활성화된 caspase와 높은 친화력을 가지는 것으로 알려진 XIAP는 caspase-9 및 -3와 결합하여 apoptosis를 직접 적으로 억제하는 것으로 알려져 있으며, CIAP-1 및 CIAP-2도 각각 다양한 caspase와의 결합을 통하여 apoptosis를 억제하 는 것으로 알려져 있다[18, 44,47]. 따라서 EESB가 IAP family 인자들의 발현에 어떠한 영향을 미치는 지를 확인한 결과, XIAP와 cIAP-1의 발현이 감소하는 것으로 나타났으므로 $\mathrm{EESB}$ 에 의한 apoptosis에 있어서 IAP family가 일정한 영향을 미쳤을 것으로 생각된다(Fig. 5).

Caspase protease는 cystein-containing aspartate-specific protease family로서 세포가 정상적으로 성장 및 생존할 경우 에는 핵과 mitochondria의 외막에 불활성 상태인 proenzyme 형태로 존재하고 있지만 세포 내외부의 다양한 자극에 의하여 활성화되어 기질 단백질들의 분해를 유발함으로서 apoptosis 
를 유발하는 것으로 알려져 있다[5]. Caspase는 initiator caspase인 caspase-8 및 -9과 effector caspase인 caspase-3, -6 및 -7 등으로 나누어지는데 먼저 initiator caspase가 활성화 되면 하위단계에 있는 effector caspase를 활성화시킴으로서 세포의 성장 및 생존에 중요한 역할을 하는 여러 종류의 기질 단백질 들은 분해함으로서 apoptosis를 유발하는 것으로 알려져 있다 $[25,48]$. Caspase에 의하여 분해가 유발되는 대표적인 기질 단백질 중의 하나인 PARP는 DNA의 결함을 인지하는 F1 및 F2라고 하는 두 개의 zinc finger motif를 가지고 있고 molecular nick sensor 기능을 하는 N-terminal DNA binding domain과 $\mathrm{NAD}^{+}$가 결합하는 C-terminal catalytic domain으로 구성되어 있으며, DNA repair에 관여하는 것으로 알려져 있 다[9, 35]. Effector caspase인 caspase-3 및 -7이 활성화 되면 $116 \mathrm{kDa}$ 의 분자량을 가진 PARP 단백질이 85 및 $24 \mathrm{kDa}$ 의 단편으로 잘리게 되면서 PARP의 효소적 기능의 상실로 인하 여 정상적인 DNA repair 과정이 억제되어진다[24, 28]. $\beta$ -catenin은 catenin family에 속하는 세포질 단백질 $(a, \beta$ 및 $\mathrm{\gamma})$ 로서 E-cadeherin과 결합하여 세포 연접기능에 중요한 역할을 하며 세포 내 골격의 유지와 다양한 부착성 세포의 전사 조절 에 관여한다. 정상 세포의 경우 $\beta$-catenin은 $92 \mathrm{kDa}$ 의 분자량 을 가지나 세포 유착성 apoptosis (adherent cell apopotosis)가 일어나면 $62-72 \mathrm{kDa}$ 로 단편화가 일어나는 것으로 알려져 있다 $[14,22,53]$. 또한 최근 연구에 의하면 PLC-81은 phosphatidylinositol 4,5-bisphosphate (PI 4,5- $\mathrm{P}_{2}$ )를 가수분해 시켜 protein kinase C (PKC) activator인 diacylglycerol 및 세포 내 $\mathrm{Ca}^{2+}$ 조절에 중요한 역할을 하는 inositol 1,4,5-trisphosphate (IP3) 를 생산한다. 따라서 PLC-81 역시 세포의 증식에 중심적인 역할을 하는 것으로 알려져 있으며, 활성화된 caspase에 의하 여 분해됨으로서 apoptosis 유발에 관여하므로 상기 두 종류 의 단백질과 함께 apoptosis 유발의 생화학적 표식자로 사용 이 되고 있다 $[1,36]$. 따라서 본 연구에서는 apoptosis 유발에 직접적으로 관여하는 것으로 알려진 caspase-3, -8 및 -9 의 발 현에 미치는 $\mathrm{EESB}$ 의 영향에 대해서 조사하였다. 결과에서 볼 수 있듯이 EESB는 death receptor에 의하여 활성화 되는 것으 로 알려진 caspase-8 및 세포질로 방출된 cytochrome 에 의하 여 활성화 되는 것으로 알려진 caspase-9의 활성화를 유발하였 으며, caspase cascade에 의하여 apoptosis에 직접적으로 관여 하는 caspase-3의 활성도 증가시키는 것으로 나타났다(Fig. 5). 또한 활성화된 caspase-3에 의하여 분해가 일어나는 기질 단백 질인 PARP, $\beta$-catenin 및 PLC-81의 경우 EESB 처리에 의하여 모두 단편화가 유발되는 것으로 나타났다. 이상의 결과에서 Caki-1 세포에서 EESB 처리에 의하여 유발되는 apoptosis는 death receptor 및 Bcl-2 family의 발현변화에 따른 미토콘드리 아 기능 이상 및 caspase의 활성화가 중요한 역할을 하는 것으 로 나타났으므로 pan-caspases inhibitor인 z-VED-fmk를 이용 하여 caspase의 활성을 억제하였을 경우에 $\mathrm{EESB}$ 에 의하여 유
발되는 apoptosis가 억제되는 지를 여러 가지 방법을 이용하 여 확인하였다. Fig. 6의 결과에서 알 수 있듯이 EESB 단독 처리에 의하여 유발된 apoptotic body 형성, sub-G1기 세포의 빈도 증가, 증식억제 및 DNA 단편화 현상이 z-VED-fmk 선처 리에 의한 caspase 활성 억제를 통하여 현저하게 억제되는 것 으로 나타났다.

이상의 결과를 종합해 보면 인체 신세포암 Caki-1 세포에 EESB를 처리하였을 경우에 유발되는 apoptosis는 DR4 및 FasL의 발현 증가를 통한 caspase-8의 활성화와 이로 인한 Bid 단백질의 단편화와 함께 $\mathrm{Bax}$ 의 발현 증가에 따른 미토콘드리 아 기능 이상에 의하여 caspase-9 및 -3의 활성화 유발과 기질 단백질들의 분해가 중요한 역할을 하는 것으로 생각되어지며, IAP family 중 XIAP 및 cIAP-1의 발현 감소로 인하여 caspase 의 활성이 억제되지 못하는 것도 apoptosis 유도에 어느 정도 관여했을 것으로 생각되어진다. 따라서 $\mathrm{EESB}$ 처리에 의하여 유발되는 apoptosis는 extrinsic 및 intrinsic pathway를 모두 경유하는 multiple apoptotic pathway에 의하여 조절되며, 이 때 caspases가 중요한 역할을 한다는 것을 알 수 있었다.

\section{감사의 글}

본 연구는 정부(교육과학기술부)의 재원으로 한국연구재단 의 지원을 받아 수행된 연구(No. 2012046358)의 일부임.

\section{References}

1. Bae, S. S., Perry, D. K., Oh, Y. S., Choi, J. H., Galadari, S. H., Ghayur, T., Ryu, S. H., Hannun, Y. A. and Suh, P. G. 2000. Proteolytic cleavage of phospholipase C-gamma1 during apoptosis in Molt-4 cells. FASEB J 14, 1083-1092.

2. Baliga, B. and Kumar, S. 2003. Apaf-1/cytochrome $c$ apoptosome: an essential initiator of caspase activation or just a sideshow? Cell Death Differ 10, 16-18.

3. Bohn, O. L., De las Casas, L. E. and Leon, M. E. 2009. Tumor-to-tumor metastasis: Renal cell carcinoma metastatic to papillary carcinoma of thyroid-report of a case and review of the literature. Head Neck Pathol 3, 327-330.

4. Burnett, B. P., Jia, Q., Zhao, Y. and Levy, R. M. 2007. A medicinal extract of Scutellaria baicalensis and Acacia catechu acts as a dual inhibitor of cyclooxygenase and 5-lipoxygenase to reduce inflammation. J Med Food 10, 442-451.

5. Chai, F., Truong-Tran, A. Q., Ho, L. H. and Zalewski, P. D. 1999. Regulation of caspase activation and apoptosis by cellular zinc fluxes and zinc deprivation: A review. Immunol Cell Biol 77, 272-278.

6. Checinska, A., Hoogeland, B. S., Rodriguez, J. A., Giaccone, G. and Kruyt, F. A. 2007. Role of XIAP in inhibiting cisplatin-induced caspase activation in non-small cell lung cancer cells: a small molecule Smac mimic sensitizes for chemotherapy-induced apoptosis by enhancing caspase- 3 
activation. Exp Cell Res 313, 1215-1224.

7. Choufani, E., Diligent, J., Galois, L. and Mainard, D. 2011. Metastatic renal cell carcinoma presenting as foot metastasis: case report and review of the literature. J Am Podiatr Med Assoc 101, 265-268.

8. Columbano, A. 1995. Cell death: current difficulties in discriminating apoptosis from necrosis in the context of pathological processes in vivo. J Cell Biochem 58, 181-190.

9. de Murcia, G. and Ménissier de Murcia, J. 1994. Poly(ADP-ribose) polymerase: a molecular nick-sensor. Trends Biochem Sci 19, 172-176

10. Deveraux, Q. L. and Reed, J. C. 1999. IAP family proteins--suppressors of apoptosis. Genes Dev 13, 239-252.

11. Donovan, M. and Cotter, T. G. 2004. Control of mitochondrial integrity by $\mathrm{Bcl}-2$ family members and caspase-independent cell death. Biochim Biophys Acta 1644, 133-147.

12. Du, J., Chen, G. G., Vlantis, A. C., Chan, P. K., Tsang, R. K. and van Hasselt, C. A. 2004. Resistance to apoptosis of HPV 16-infected laryngeal cancer cells is associated with decreased Bak and increased Bcl-2 expression. Cancer Lett 205, 81-88.

13. Escudier, B., Eisen, T. and Stadler, W. M. 2007. Sorafenib in advanced clear-cell renal-cell carcinoma. $N$ Engl J Med 356, 125-134.

14. Fukuda, K. 1999. Apoptosis-associated cleavage of $\beta$-catenin in human colon cancer and rat hepatoma cells. Int J Biochem Cell Biol 31, 519-529.

15. Gao, J., Morgan, W. A., Sanchez-Medina, A. and Corcoran, O. 2011. The ethanol extract of Scutellaria baicalensis and the active compounds induce cell cycle arrest and apoptosis including upregulation of p53 and Bax in human lung cancer cells. Toxicol Appl Pharmacol 254, 221-228.

16. Gao, Z., Huang, K., Yang, X. and Xu, H. 1999. Free radical scavenging and antioxidant activities of flavonoids extracted from the radix of Scutellaria baicalensis Georgi. Biochim Biophys Acta 1472, 643-650.

17. Han, S. I., Kim, Y. S. and Kim, T. H. 2008. Role of apoptotic and necrotic cell death under physiologic conditions. $B M B$ Rep 41, 1-10.

18. Huang, Y., Park, Y. C., Rich, R. L., Segal, D., Myszka, D. G. and $\mathrm{Wu}, \mathrm{H}$. 2001. Structural basis of caspase inhibition by XIAP: differential roles of the linker versus the BIR domain. Cell 104, 781-790.

19. Huang, Y., Tsang, S. Y., Yao, X. and Chen, Z. Y. 2006. Biological properties of baicalein in cardiovascular system. Curr Drug Targets Cardiovasc Haematol Disord 5, 177-184, 2005.

20. Huerta, S., Goulet, E. J., Livingston, E. H. 2006. Colon cancer and apoptosis. Am J Surg 191, 517-526.

21. Jin, Z. and El-Deiry, W. S. 2005. Overview of cell death signaling pathways. Cancer Biol Ther 4, 139-163.

22. Johnson, J. P. 1999. Cell adhesion molecules in the development and progression of malignant melanoma. Cancer Metastasis Rev 18, 345-357.

23. Jung, H. S., Kim, M. H., Gwak, N. G., Im, Y. S., Lee, K. Y., Sohn, Y., Choi, H. and Yang, W. M. 2012. Antiallergic effects of Scutellaria baicalensis on inflammation in vivo and in vitro. J Ethnopharmacol 141, 345-349.

24. Kaufmann, S. H., Desnoyers, S., Ottaviano, Y., Davidson, N.E. and Poirier, G. G. 1993. Specific proteolytic cleavage of poly(ADP-ribose) polymerase: an early marker of chemotherapy-induced apoptosis. Cancer Res 53, 3976-3985.

25. Kim, R., Emi, M. and Tanabe, K. 2005. Caspase-dependent and -independent cell death pathways after DNA damage (Review). Oncol Rep 14, 595-599.

26. Kimberley, F. C. and Screaton, G. R. 2004. Following a TRAIL: update on a ligand and its five receptors. Cell Res 14, 359-372.

27. Lam, T. L., Lam, M. L., Au, T. K., Ip, D. T., Ng, T. B., Fong, W. P. and Wan, D. C. 2000. A comparison of human immunodeficiency virus type-1 protease inhibition activities by the aqueous and methanol extracts of Chinese medicinal herbs. Life Sci 67, 2889-2896.

28. Lazebnik, Y. A., Kaufmann, S. H., Desnoyers, S., Poirier, G. G. and Earnshaw, W. C. 1994. Cleavage of poly(ADP-ribose) polymerase by a proteinase with properties like ICE. Nature 371, 346-347.

29. Li, H., Zhu, H., Xu, C. J. and Yuan, J. 1998. Cleavage of BID by caspase 8 mediates the mitochondrial damage in the Fas pathway of apoptosis. Cell 94, 491-501.

30. Lieberthal, W., Koh, J. S. and Levine, J. S. 1998. Necrosis and apoptosis in acute renal failure. Semin Nephrol 18, 505-518.

31. Loeb, L. A., Loeb, K. R. and Anderson, J. P. 2003. Multiple mutations and cancer. Proc Natl Acad Sci USA 100, 776-781.

32. Lu, Y., Joerger, R. and $\mathrm{Wu}, \mathrm{C}$. 2011. Study of the chemical composition and antimicrobial activities of ethanolic extracts from roots of Scutellaria baicalensis Georgi. J Agric Food Chem 59, 10934-10942.

33. Luo, X., Budihardjo, I., Zou, H., Slaughter, C. and Wang, X. 1998. Bid, a Bcl2 interacting protein, mediates cytochrome $c$ release from mitochondria in response to activation of cell surface death receptors. Cell 94, 481-490.

34. Motzer, R. J., Bander, N. H. and Nanus, D. M. 1996. Renal-cell carcinoma. $N$ Engl J Med 335, 865-875.

35. Muller, S., Briand, J. P., Barakat, S., Lagueux, J., Poirier, G. G., De Murcia, G. and Isenberg, D. A. 1994. Autoantibodies reacting with poly(ADP-ribose) and with a zinc-finger functional domain of poly(ADP-ribose) polymerase involved in the recognition of damaged DNA. Clin Immunol Immunopathol 73, 187-196.

36. Myklebust, J. H., Blomhoff, H. K., Rusten, L. S., Stokke, T. and Smeland, E. B. 2002. Activation of phosphatidylinositol 3-kinase is important for erythropoietin-induced erythropoiesis from CD34(+) hematopoietic progenitor cells. Exp Hematol 30, 990-1000.

37. Nagai, T., Suzuki, Y., Tomimori, T. and Yamada, H. 1995. Antiviral activity of plant flavonoid, 5,7,4'-trihydroxy-8methoxyflavone, from the roots of Scutellaria baicalensis against influenza A (H3N2) and B viruses. Biol Pharm Bull 18, 295-299.

38. Nicotera, P., Leist, M. and Ferrando-May, E. 1999. Apoptosis 
and necrosis: different execution of the same death. Biochem Soc Symp 66, 69-73.

39. Okada, H. and Mak, T. W. 2004. Pathways of apoptotic and non-apoptotic death in tumour cells. Nat Rev Cancer 4, 592-603.

40. Park, K. I., Park, H. S., Kang, S. R., Nagappan, A., Lee, D. H., Kim, J. A., Han, D. Y. and Kim, G. S. 2011. Korean Scutellaria baicalensis water extract inhibits cell cycle G1/S transition by suppressing cyclin D1 expression and matrix-metalloproteinase-2 activity in human lung cancer cells. J Ethnopharmacol 133, 634-641.

41. Peták, I. and Houghton, J. A. 2001. Shared pathways: death receptors and cytotoxic drugs in cancer therapy. Pathol Oncol Res 7, 95-106.

42. Ratain, M. J., Eisen, T. and Stadler, W. M. 2006. Phase II placebo-controlled randomized discontinuation trial of sorafenib in patients with metastatic renal cell carcinoma. J Clin Oncol 24, 2505-2512.

43. Rossé, T., Olivier, R., Monney, L., Rager, M., Conus, S., Fellay, I., Jansen, B. and Borner, C. 1998. Bcl-2 prolongs cell survival after Bax-induced release of cytochrome $c$. Nature 391, 496-499.

44. Roy, N., Deveraux, Q. L., Takahashi, R., Salvesen, G. S. and Reed, J. C. 1997. The c-IAP-1 and c-IAP-2 proteins are direct inhibitors of specific caspases. EMBO J 16, 6914-6925.

45. Salvesen, G. S. and Duckett, C. S. 2002. IAP proteins: blocking the road to death's door. Nat Rev Mol Cell Biol 3, 401-410. 46. Scaffidi, C., Fulda, S., Srinivasan, A., Friesen, C., Li, F.,
Tomaselli, K. J., Debatin, K. M., Krammer, P. H and Peter, M. E. 1998. Two CD95 (APO-1/Fas) signaling pathways. EMBO J 17, 1675-1687.

47. Scott, F. L., Denault, J. B., Riedl, S. J., Shin, H., Renatus, M. and Salvesen, G. S. 2005. XIAP inhibits caspase-3 and -7 using two binding sites: evolutionarily conserved mechanism of IAPs. EMBO J 24, 645-655.

48. Stennicke, H. R. and Salvesen, G. S. 1998. Properties of the caspases. Biochim Biophys Acta 1387, 17-31.

49. van Delft, M. F. and Huang, D. C. 2006. How the Bcl-2 family of proteins interact to regulate apoptosis. Cell Res 16, 203-213.

50. Vilches Troya, J. 2005. Understanding cell death: a challenge for biomedicine. An R Acad Nac Med 122, 631-656.

51. Waisundara, V. Y., Hsu, A., Huang, D. and Tan, B. K. 2008. Scutellaria baicalensis enhances the anti-diabetic activity of metformin in streptozotocin-induced diabetic Wistar rats. Am J Chin Med 36, 517-540.

52. Wang, C. Z., Li, X. L., Wang, Q. F., Mehendale, S. R. and Yuan, C. S. 2010. Selective fraction of Scutellaria baicalensis and its chemopreventive effects on MCF-7 human breast cancer cells. Phytomedicine 17, 63-68.

53. Wijnhoven, B. P., Dinjens, W. N. and Pignatelli, M. 2000. E-cadherin-catenin cell-cell adhesion complex and human cancer. Br J Surg 87, 992-1005.

54. Zimmermann, K. C., Bonzon, C. and Green, D. R. 2001. The machinery of programmed cell death. Pharmacol Ther 92, 57-70.

\section{초록 : 황금(黃芩) 에탄올 추출물에 의한 인체 신세포암 Caki-1 세포의 자가세포사멸 유도}

\section{황원덕 ${ }^{1} \cdot$ 임용균 ${ }^{1} \cdot$ 손병일 ${ }^{2} \cdot$ 박 철 $^{4} \cdot$ 박동일 $^{1} \cdot$ 최영현 ${ }^{23,5}{ }^{*}$}

(동의대학교 한의과대학 ${ }^{1}$ 내과학교실 및 ${ }^{2}$ 생화학교실, ${ }^{3}$ Blue-Bio Industry RIC, ${ }^{4}$ 자연과학대학 분자생물학과 및 ${ }^{5}$ 항노화연구소)

꿀풀과(Labiatae)에 속하는 황금(黃芩, S. baicalensis)은 한국, 중국, 몽골 및 시베리아 동부 등지에 분포하는 여 러해살이 초본식물로서 예로부터 민간처방 약재로 사용되었으며, 한방에서는 뿌리 말린 것을 이질, 발열 및 황달 의 치료제로 사용되고 있다. 또한 최근 연구에 따르면 황금 추출물은 항염증, 항당뇨, 항균, 항알레르기, 항바이러 스, 항고혈압, 항산화 및 항암 효능을 가지는 것으로 알려져 있으나 신세포암에서의 항암효능 및 분자생물학적 기전에 대해서는 명확히 밝혀져 있지 않다. 본 연구에서는 인체 신세포암 Caki-1 세포에서 황금 에탄올 추출물 (ethanol extract of $S$. baicalensis, EESB)이 유발하는 항암효과 및 항암기전을 조사하였다. 본 연구의 결과에 의하 면 EESB 처리에 의한 Caki-1 세포의 증식억제는 apoptosis 유발과 밀접한 연관이 있었으며, 이는 DR4 Fas ligand 및 $\mathrm{Bax}$ 단백질의 발현 증가와 $\mathrm{Bid}, \mathrm{XIAP}$ 및 CIAP-1의 발현 억제와 관련이 있었다. EESB는 또한 미토콘드리아의 기능 손상과 caspase-3의 기질단백질인 PARP, $\beta$-catenin 및 PLCy-1 단백질의 단편화를 유발하였다. 그러나 EESB 처리에 의하여 유발되었던 apoptosis가 pan-caspases inhibitor인 z-VED-fmk를 이용하여 caspases의 활성을 억제 하였을 경우 현저하게 감소되어, EESB에 의한 apoptosis 과정에 caspase의 활성 증대가 중요한 역할을 한다는 것을 알 수 있었다. 이러한 결과들은 황금의 항암작용을 이해하는데 중요한 자료가 될 것이고 나아가 향후 수행 될 추가 실험을 위한 기초 자료로서 그 가치가 매우 높을 것으로 생각된다. 